\title{
ANALYSIS OF THEORETICAL APPROACHES TO GENDER PAY GAP
}

\author{
Virginija Grybaitė \\ Vilnius Gediminas Technical University, Sauletekio al. 11, LT-10223 Vilnius, Lithuania \\ E-mail:vigryb@lrs.lt
}

Received 1509 2005; accepted 03012006

\begin{abstract}
The number of women in the world labour force is growing. Nevertheless, in spite of women's large share in the labour force, many gender inequities in the labour market, such as gender specific jobs, pay inequities are observed. Women and men do not receive equal pay for equal work. Wage discrimination is reality. Women on average have lower incomes, lower wages and less advantageous terms of employment than men. The purpose of this article is to review main theoretical approaches to the basic economic question about the gender pay gap: why do, women, on average earn less than men. Attention has been focused on basic theoretical approaches: human capital model, labour market discrimination and theory of occupational segregation. The paper is based on empirical data from Lithuania and other European Union countries.
\end{abstract}

Keywords: gender pay gap, human capital, discrimination, occupational segregation, crowding out

\section{Introduction}

In spite of women's large share in the labour force, pay inequities continue to exist. Women and men do not receive equal pay for equal work. Wage discrimination is undisputable. Generally speaking, women have lower incomes, lower wages and less advantageous terms of employment than men. In particular male - female pay differentials affect the position of women in the labour market as well as the status and power of women within the household. Gender differences at the work place are transformed into inequality after retirement. As women are low paid, the social security benefits are also low. The inequalities during their working life lead to lower retirement payments. The inequality between male and female earnings determines other negative consequences. Lower wage rate for women may increase the economic dependence of women on their male partners and this may increase their susceptibility to domestic violence. Economic equality means different things to women and men. A man in a position of economic independence is a man who does not need to work for a living. For women, being in a position of economic independence means being able to support them by paid work so that they are not dependent on a man. An increase number of divorces impact on the position of women too. Single mothers stay the sole wage earners in their families. It is important to understand the causes of pay inequities and to seek the ways resolve the problem about gender pay gap. Various economic theories have been used to explain the sources of wage discrimination, the gender wage gap. Broadly speaking such explanations can be categorized in two sets: differences in qualifications, otherwise - human capital model and different positions on the labour market - models of labour market discrimination. Empirical evidences from Lithuania and other European Union countries are given in section number 4 .

\section{The human capital model}

Gender differences in qualifications have been analysed within the human capital model, which basic idea is that every person has some form of human capital. Human capital can be determined as the abilities and skills 
people have and taken through education, training and experience. These skills are the basis for the earnings they receive. According Jacob Mincer and Solomon Polachek women choose occupations in order to minimize looses associated with their more intermittent attachment to the labour force [1]. Given the traditional division of labour by gender in the family, women tend to accumulate less labour market experience than men. Further, because women anticipate shorter and more discontinuous work live, they have lower incentives to invest in labour market - oriented formal education and on the job training, and resulting smaller human capital investments will lower their earnings relative to those of men. The longer hours that women spend on housework may also decrease the effort put into their market jobs compared to men, controlling for hours worked, and hence also reduce their productivity and wages [1]. Supposing that women choose occupations for which on-the-job training less important, gender difference in occupations would also be expected. Women may especially avoid jobs requiring large investments in skills that are unique to a particular enterprise, because the returns to such investments are reaped only as long as one remain with that employer. At the same time, employers may be reluctant to hire women for such jobs because the firm bears some of the costs of such firm - specific training and fears not getting a full return on that investment. Decision to hire one individual rather than another for jobs in which specific training is provided depends on the likelihood that training cost will be recovered and if individual will permanently separate from a firm it negatively affect this likelihood. The human capital model implies an important role for wage structure in explaining the gender wages gap. If, as human capital model propose, women have less experience than men, on average, the higher the return to experience received by workers, regardless of sex, the larger will be the gender gap in pay [2]. Economist Gary S. Becker, who was awarded the Nobel Prize in Economics (1992) for his contribution to the theory of human capital, also noted an importance of human capital theory to explanation of gender gap in earnings. As he said, traditionally, women have been far more likely than men to work part-time and intermittently partly because they usually withdrew from the labour market for a while after having children. As a result, they had fewer incentives to invest in education and training that improved earnings and job skills [3]. However, he noticed that situation has changed, decline in family size, the growth in divorce rates, and the rapid expansion of the service sector where most women were employed, the continuing economic development raised the earnings of women along with men. Women greater labour force participation also leads to greater investment in market oriented skills [4]. Although most studies suggest that human capital factors, particularly women's lesser labour market experience, are important in explaining the gender pay gap, there are different views said that human capital theory is based on broad assumption and fails to take into account the fact that all decisions are made in a normative context where there are set ideas about what women and men ought to do. Human capital model critics claim that women and men cannot be studied as autonomous individuals and the different conditions they face in their working life must be put in material and social context [5]. Moreover, human capital differences may not explain the entire wage gap. Only a limited part of the wage gaps can be explained by included factors such as education, work experience. As seen in Lithuania data - women are actually better educated than men on average, but they work more often in low wages areas. Work experience is not important here because Lithuanian women have on average at least as long experience and tenure as men. The identical situation is observed in most European countries $[6,7]$.

\section{Labour market discrimination}

The portion of the pay gap that is not due to gender differences in qualifications is generally presumed to be due to labour market discrimination. Various concepts of discrimination are used to describe and analyse conditions on the labour market. How economic discrimination is determinate. This is not referring to the fact that different jobs pay different amounts that unskilled workers receive less than skilled workers. Economic discrimination is defined as when otherwise identical workers receive different pay doing the same job, or are given different chances of employment or promotion. It is the presence of different pay for workers of the same ability but who are in different groups, e.g. male, female [8]. In other words, can be defined as direct discrimination. The term distribution discrimination pertains to women facing limited access to attractive position within a work organization and denotes unequal treatment of women in decisions about recruitment and promotion. The term value discrimination means that jobs performed mostly by women are paid less than those jobs that are performed primarily by men. Wage discrimination is the material foundation for the subordination of women and for the lack of economic equality [9]. Labour market discrimination affects women's wages and occupations. The standard economic analysis of discrimination is based on Gary 
Becker work. Becker assumed that some individuals have what he called a taste for discrimination. A taste for discrimination is not just a like or dislike but rather a like that an individual is willing to act on. In his word "if an individual has a taste for discrimination, he must act as if he were willing to pay something, either directly or in the form of a reduced income, to be associated with some persons rather than others" [10]. Becker's analysis of discrimination is inlayed within the conventional economic analysis of utilitymaximizing individuals and profit-maximizing firms that often straiten their behaviour. Becker's model suggests that employees, co-workers or customers have tastes for discrimination against women that lead to a segregated workforce. He analysed such sources of discrimination: employers who had tastes for discrimination regarding their employees (employer discrimination), employees who had tastes for discrimination regarding their co-workers (employee discrimination) and customers who had tastes for discrimination regarding the suppliers with whom they interacted (customer discrimination). Employers who willingly employ women as secretaries may be reluctant to hire them as constructor. Men may willing to work with women subordinate position but dislike when women in superior position. Customers who like to purchase flowers from women may avoid women who sell cars. Model of statistical discrimination has been developed by Edmund Phelps [11]. He suggests that employers judge individual women in term of the average characteristics of the group. Employers are often concern that women do not take their careers as seriously as men, they expect that women quit their jobs when they have children. Consequently is risky and more dangerous to employ women than employing men. If employers believe, that on average, women are less productive, less stable employees, statistical discrimination against individual women may result. The other theory of discrimination is known as crowding. Crowding model developed by Barbara Bergmann [12]. According suggested hypothesis, because women are denied access to many occupations, they are crowded into a limited number of remaining occupations. The existence and proceed of occupational segregation by gender have caused to argue that is the result of a crowding policy intending to lower wages in certain occupations. It is easy to explain the crowding hypothesis on the ground of labour supply - demand curve, when supply is small relative to demand then the wage is high, and when in market crowding causes supply to be large relative to demand, wages is comparatively low. Although supply-demand law easily explains the effects of crowding, the phenomenon of crowding itself is less easily explains. The fundamental assumption is that surplus supply of female labour leads to low wages wherever it occurs. The overcrowding model is consisted with the evidence that else being equal, earnings tend to be lower in predominantly female occupations than in predominantly male occupations. The crowding of women in an occupation guide to reduced wages - to a gender deduction. The fact that men in predominantly female occupations also receive low wages is not necessarily inconsistent (contradictory) with the crowding hypothesis. Although men as a group not excluded from male sector, some of them may enter female occupations because they have a strong preference or particular skills or may be poorly informed about alternative opportunities. They will accept the lower wages paid in female jobs. This theory is useful to understand sex inequality in labour market and consequently pay gap, but this theory does not answer to important question- why female jobs are crowded. Bren and Garcia-Penalosa has proposed another approach of gender segregation [13]. In their model individuals have imperfect information about their probability of success and base career choices on prior beliefs about these probabilities. Moreover, past differences in the preferences affect the beliefs of the current generation, and so career choices differ even when men and women become identical in their current preferences and traits. Regardless of the underlying reason for crowding, if crowding is the sole cause of gender pay gap, there should be no statistically significant difference in the average wages paid to males and females within an occupational except for differences in productivity ant other individual traits. The monopsony theory says that where the employer is in a monopoly position, the lack of competition leads to a low price for labour. One way in which a firm gains monopsony power is when it is large buyer of labour relative to the size of a particular market. A controversial approach to the pay gap question Warren Farrell set out in his new book [14]. Based on his research, he came to the conclusion that women pay an economic price for seeking more flexible, less risky, and more fulfilling careers. These jobs usually pay less. For example, the librarian with a graduate degree will earn less than a garbage collector without education. The garbage collector gets higher salaries because his work involves greater risk and less pleasant working condition. According Warren Farrell the idea that bias-based unequal pay for women is largely a myth, and that women are most often paid less than men not because they are discriminated against, but because they have made lifestyle choices that affect their ability to earn. In his book he presents concrete ways for any woman to 
increase her pay. Among his recommending ways are that women choose a career with higher financial and emotional risks (i.e.: venture capitalist), find a speciality that requires frequent updating - and stay current, seek out more lucrative sub fields (surgeon vs. psychiatrist), get hazard pay without the hazards (i.e.: be an administrator in the Air Force), relocate especially to undesirable locations at the company's behest, require less job security [14]. He rejects presumption that women are discriminated against in the workplace and that women's low wages is result of discrimination.

\section{Pay differentials and occupational segregation (empirical evidences)}

The number of women in the labour force is growing. Women represent over 40 per cent of the global labour force. Between 1995 and 2001, women participation in the EU labour market increased by about 3.6 percentage points (from 56.6 per cent to 60.2 per cent) against an increase in the male rate of only 0.5 percentage points (from 77.8 per cent to 78.3 per cent [15]. In Lithuania labour market women employment rate increased from 46.4 per cent in 1997 to 58.4 per cent in 2003 (Table 1). But in spite of increasing number of women in the labour force, women earn, on average, considerably less than men. Women in the

Table 1. Labour force activity rate, employment rate by sex in ages $15-64$ (per cent) $[6,16]$

\begin{tabular}{|c|c|c|c|c|}
\hline \multirow{2}{*}{} & \multicolumn{2}{|c|}{ Activity rate } & \multicolumn{2}{c|}{ Employment rate } \\
\cline { 2 - 5 } & Women & Men & Women & Men \\
\hline 1997 & 53.9 & 70.3 & 46.4 & 60.3 \\
\hline 1998 & 54.9 & 69.6 & 48.2 & 59.6 \\
\hline 1999 & 55.7 & 69.2 & 48.7 & 58.4 \\
\hline 2000 & 67.1 & 74.2 & 57.5 & 60.1 \\
\hline 2001 & 65.8 & 73.4 & 55.9 & 58.5 \\
\hline 2002 & 65.7 & 73.2 & 57.1 & 62.3 \\
\hline 2003 & 66.5 & 73.1 & 58.4 & 63.7 \\
\hline
\end{tabular}

Lithuanian labour market, on average are paid 80 per cent of men's wages (see Table 2). The gender pay gap prevails in all the European Union countries (Table 3).

Table 3. Gender pay gap in the European Union countries (Eurostat's database New Cronos (February, 2005) per cent. (Gender pay gap - difference between men's and women's average gross hourly earnings as a percentage of men's average gross hourly earnings) [7]

\begin{tabular}{|l|c|c|c|c|}
\hline Countries & 2000 & 2001 & 2002 & 2003 \\
\hline Ireland & 19 & 17 & $\ldots$ & 14 \\
\hline Austria & 20 & 20 & $\ldots$ & 17 \\
\hline Belgium & 13 & 12 & $\ldots$ & $\ldots$ \\
\hline Czech Republic & 22 & 20 & 19 & 19 \\
\hline Denmark & 15 & 15 & 18 & 18 \\
\hline Estonia & 25 & 24 & 24 & 24 \\
\hline Greece & 15 & 18 & 17 & 11 \\
\hline Spain & 15 & 17 & 21 & 18 \\
\hline Italy & 6 & 6 & $\ldots$ & $\ldots$ \\
\hline United Kingdom & 21 & 21 & 23 & 22 \\
\hline Cyprus & 26 & 26 & 25 & 25 \\
\hline Latvia & 20 & 16 & 16 & 16 \\
\hline Poland & & 12 & 11 & 11 \\
\hline Lithuania & 16 & 16 & 16 & 17 \\
\hline Luxemburg & 15 & 16 & 17 & 15 \\
\hline Malta & 11 & 9 & 6 & 4 \\
\hline Netherlands & 21 & 19 & 19 & 18 \\
\hline Portugal & 8 & 10 & 8 & 9 \\
\hline France & 13 & 14 & 13 & 12 \\
\hline Slovak Republic & 22 & 23 & 27 & 23 \\
\hline Slovenia & 12 & 11 & 9 & $\ldots$ \\
\hline Finland & 17 & 17 & 20 & $\ldots$ \\
\hline Sweden & 18 & 18 & 17 & 16 \\
\hline Hungary & 21 & 16 & 14 \\
\hline Germany & 21 & 23 \\
\hline
\end{tabular}

Table 2. Monthly average gross earnings by economic sector (LTL) (Sole proprietorships are excluded) [6]

\begin{tabular}{|c|c|c|c|c|c|c|}
\hline & \multicolumn{2}{|c|}{2000} & \multicolumn{2}{c|}{2002} & \multicolumn{2}{c|}{2003} \\
\hline & Women & Men & Women & Men & Women & 1050 \\
\hline Whole economy & 956 & 1170 & 1010 & 1244 & 1297 \\
\hline Public sector & 980 & 1272 & 1018 & 1360 & 1065 & 1416 \\
\hline Private sector & 918 & 1087 & 998 & 1174 & 1029 & 1228 \\
\hline
\end{tabular}


High level of segregation has been considered to be responsible for the inequality between men and women earnings and for constrains on careers. Occupational segregation by sex dominates not only in the EU but also around the world. Men and women are disproportionately represented in particular occupations. Broadly speaking, women's jobs involve caring, nurturing and service, while men monopolise manual and technical jobs associated with machinery or physical products that are considered to be "heavy". Men are predominant in craft and related trades and plant and machine operation, also skilled agricultural and fishery. At the top of occupational hierarchy men occupy the legislative and managerial occupations; in contrast, most of women are service and sales workers. Moreover, women have supervisory responsibilities much less frequently than men: 16 per cent of men in paid employment in the EU had supervisory responsibilities and an additional 19 per cent intermediate responsibilities compared to less than 9 percent to 16 per cent, respectively to women. Women are furthermore often in non-standard employment such as fixed-term and part-time work. Compared to 6.2 per cent of all employed men, 33.4 per cent of all women work in part-time [7]. As shown in Table 4 and 5, there is occupational segregation and sex segregation in terms of industries.
The empirical evidences given above prove the fact that women and men face different situation in the labour market, women, on average are in a worse position then men in economic terms.

\section{Conclusions}

The paper describes main theoretical approaches to the basic economic question about the gender pay gap: why do, women, on average earn less than men. In this article described theories are grouped in two sets: human capital model, which emphasizing differences in qualifications and models of labour market discrimination - different positions on the labour market.

Described Human capital model analyse gender differences in qualifications. Its basic idea is that every person has some form of human capital that can be determined as the abilities and skills people have and taken through education, training and experience. According to human capital model if women have less experience in labour market, less education and et cetera, women rightfully receive lower pay. Although the human capital model is important in explaining the gender pay gap, however, it may not explain the entire wage gap. Only a limited part of the wage gaps can be explained by included factors such as education, work experience.

Table 4. Employed population by occupation and sex (average annual number, thousand) [6, 16]

\begin{tabular}{|l|c|c|c|c|c|c|c|c|c|c|}
\hline & \multicolumn{2}{|c|}{2000} & \multicolumn{2}{c|}{2001} & \multicolumn{2}{c|}{2002} & \multicolumn{2}{c|}{2003} & \multicolumn{2}{c|}{2004} \\
\cline { 2 - 12 } & Men & Women & Men & Women & Men & Women & Men & Women & Men & Women \\
\hline $\begin{array}{l}\text { Legislators, senior } \\
\text { officers and managers }\end{array}$ & 66.1 & 49.7 & 51,8 & 47,3 & 59,8 & 46,1 & 65,9 & 41,7 & 63,1 & 45,9 \\
\hline Professionals & 55.7 & 147.0 & 59,8 & 148,3 & 61,3 & 144,2 & 69,8 & 150,7 & 80,2 & 157,6 \\
\hline $\begin{array}{l}\text { Technicians and } \\
\text { associate professionals }\end{array}$ & 36,8 & 74,3 & 39,3 & 81,7 & 41,5 & 98,5 & 36,3 & 92,9 & 35,7 & 90,5 \\
\hline Clerks & 12,3 & 55,6 & 9,0 & 49,5 & 12,1 & 43,3 & 10,4 & 41,7 & 10,6 & 43,8 \\
\hline $\begin{array}{l}\text { Service workers and } \\
\text { shop and market sales } \\
\text { workers }\end{array}$ & 54,7 & 119,5 & 50,6 & 122,8 & 52,6 & 114,1 & 54,2 & 117,9 & 53,5 & 113,6 \\
\hline $\begin{array}{l}\text { Skilled agricultural and } \\
\text { fishery workers }\end{array}$ & 119,3 & 95,3 & 121,5 & 80,7 & 121,3 & 88,9 & 121,1 & 90,6 & 105,9 & 81,7 \\
\hline $\begin{array}{l}\text { Craft and related trades } \\
\text { workers }\end{array}$ & 166,2 & 69,4 & 161,5 & 71,8 & 172,5 & 71,1 & 177,8 & 73,8 & 185,1 & 75,3 \\
\hline $\begin{array}{l}\text { Plant and machine } \\
\text { operators and assembles }\end{array}$ & 110,5 & 20,3 & 114,9 & 20,2 & 117,3 & 20,3 & 111,5 & 20,7 & 117,2 & 17,0 \\
\hline Elementary occupations & 62,9 & 80,2 & 52,7 & 64,4 & 66,1 & 71,5 & 76,2 & 78,8 & 77,8 & 76,8 \\
\hline $\begin{array}{l}\text { Armed forces } \\
\text { employees) }\end{array}$ & 2,1 & 0,1 & 3,4 & 0,3 & 3,2 & $\ldots \ldots$ & 3,1 & $\ldots$. & 4,8 & 0,2 \\
\hline
\end{tabular}


Table 5. Number of employed population by kind of activity and sex, per cent and average monthly gross earnings (LTL) of employees in the whole economy by kind of economic activity and sex 2003 (individual (personal) enterprises excluded) [6]

\begin{tabular}{|c|c|c|c|c|c|c|c|c|c|c|}
\hline \multirow[t]{2}{*}{$\begin{array}{l}\text { Kind of economic } \\
\text { activity }\end{array}$} & \multicolumn{2}{|c|}{2000} & \multicolumn{2}{|c|}{2001} & \multicolumn{2}{|c|}{2002} & \multicolumn{2}{|c|}{2003} & \multicolumn{2}{|c|}{$\begin{array}{c}\text { Earnings LTL, } \\
2003\end{array}$} \\
\hline & Men & Women & Men & Women & Men & Women & Men & Women & Men & Women \\
\hline $\begin{array}{l}\text { Agriculture, hunting } \\
\text { and forestry }\end{array}$ & 58,6 & 41,4 & 61,7 & 38,2 & 60,4 & 39,6 & 59,6 & 40,4 & 907,6 & 795,8 \\
\hline Fishing & 82,9 & 17,1 & 96,2 & 3,8 & 100 & - & 93,3 & 6,7 & 776,8 & 672,5 \\
\hline Mining and quarrying & 48,4 & 51,6 & 78,6 & 21,4 & 69,8 & 32,6 & 76,5 & 23,5 & 1599,3 & 1518,9 \\
\hline $\begin{array}{l}\text { Manufacturing } \\
\text { industry }\end{array}$ & 50,7 & 49,2 & 47,5 & 52,5 & 49,8 & 50,1 & 49,1 & 50,9 & 1263,6 & 979,9 \\
\hline $\begin{array}{l}\text { Electricity, gas and } \\
\text { water supply }\end{array}$ & 68,8 & 31,5 & 82,3 & 17,7 & 84,5 & 15,5 & 73,7 & 26,3 & 1619,4 & 1391,0 \\
\hline Construction & 91,5 & 8,5 & 91,4 & 8,5 & 90,2 & 9,7 & 89,8 & 10,2 & 1058,3 & 1039,4 \\
\hline $\begin{array}{l}\text { Wholesale and retail } \\
\text { trade; repair of motor } \\
\text { vehicles, motorcycles } \\
\text { and personal and } \\
\text { household goods }\end{array}$ & 45,1 & 54,8 & 48,9 & 51,1 & 49,1 & 50,9 & 48,0 & 52,1 & 1226,6 & 957,9 \\
\hline Hotels and restaurants & 26,9 & 73,1 & 22,9 & 77,1 & 22,5 & 77,9 & 18,7 & 81,3 & 857,8 & 706,0 \\
\hline $\begin{array}{l}\text { Transport, storage and } \\
\text { communication }\end{array}$ & 69,3 & 30,6 & 69,7 & 30,3 & 72,5 & 27,5 & 75,7 & 24,3 & 1351,5 & 1297,2 \\
\hline $\begin{array}{l}\text { Financial } \\
\text { intermediation }\end{array}$ & 42,8 & 57,2 & 48,6 & 51,4 & 39,3 & 60,7 & 35,1 & 64,9 & 3602,6 & 2137,7 \\
\hline $\begin{array}{l}\text { Real estate, renting } \\
\text { and business activities }\end{array}$ & 53,2 & 46,8 & 51,3 & 48,7 & 48,8 & 51,2 & 50,1 & 49,9 & 1392,3 & 1180,8 \\
\hline $\begin{array}{l}\text { Public administration } \\
\text { and defence; } \\
\text { compulsory social } \\
\text { security }\end{array}$ & 54,8 & 45,2 & 54,7 & 45,3 & 50,3 & 49,7 & 60,2 & 39,8 & 1835,8 & 1724,8 \\
\hline Education & 21,5 & 78,5 & 20,5 & 79,5 & 21,4 & 78,6 & 20,7 & 79,3 & 1011,1 & 963,8 \\
\hline Health and social work & 14,1 & 85,9 & 12,3 & 87,7 & 14,9 & 85,1 & 14,4 & 85,5 & 1080,9 & 873,6 \\
\hline $\begin{array}{l}\text { Other community, } \\
\text { social and personal } \\
\text { service activities }\end{array}$ & 44,6 & 55,4 & 31,6 & 68,4 & 41,6 & 58,4 & 38,6 & 61,4 & 1112,7 & 911,2 \\
\hline
\end{tabular}

The unexplained difference in pay presumed to be due to discrimination.

Labour market discrimination models: employer discrimination, employee discrimination, and customer discrimination, statistical discrimination explain the sources of discrimination in the labour market, show, how prejudices could find way into demand of labour and could affect the relative earnings of women. These models (except statistical discrimination) suggest that practice of discrimination is costly to firms but it remains unclear how described models of discrimination can persist in a competitive market.
Crowding model, developed by Barbara Bergmann is useful to understand sex inequality in labour market and consequently pay gap, but this theory does not answer to important question- why female jobs are crowded.

All the models described are useful to understand reasons of gender pay inequity, however, no one of reviewed models can be demonstrated to be superior to the others in explaining gender pay gap and in proposing the ways to solve the problem. Legislation and collective agreements, movement of trade unions play an important role to combat wage discrimination. 


\section{References}

[1] Mincer, J.; Polachek, S. Family investment in human capital: Earning of Women. Journal of Political Economy, 82 (2), 1974, p. 96-108.

[2] Blau, Francine D.; Kahn, Lawrence M. Gender Differences in Pay. Journal of Economic Perspective, Vol 14, No 4, 2000, p. 75-99.

[3] Becker, Gary S. Human capital, Effort and the sexual Division Labour. Journal of Labour Economics, Vol 3, No 5, 1985, p. 33-58.

[4] Becker, Gary S. Nobel lecture: The Economic Way of Looking at Behavior. Journal of Political Economy, 101 (3), 1993, p. 385-409.

[5] Highlighting pay differentials between women and men. Government Offices Sweden, 2000.

[6] Department of Statistics to the Government of the Republic of Lithuania (Statistics Lithuania), 2005 http://www.std.lt

[7] EUROSTAT http://www.europa.eu.int/comm/eurostat

[8] http://economics.about.com/od/economicsglossary/ index.htm. November, 2005.

[9] Arrow, K. Models of Job Discrimination. In A.H. Pascal (Ed.), Racial discrimination in economic life. Lexington, MA: Lexington Books, 1972, p. 83-102.

[10] Becker, Gary S. The economics of discrimination. Chicago: University of Chicago Press, 1971.

[11] Phelps, E. The Statistical Theory of Racism and Sexism. American Economic Review, Vol 62, 1972, p. 288.

[12] Bergmann, B. Occupational Segregation, Wages and Profits When Employers Discriminate By Race and Sex. Eastern Economic Journal, 1(2), 1974, p. 103-110.

[13] Bren, R.; Garsia-Penalosa, C. Bayesian Learning and Gender Segregation. Journal of Labour Economics, 20 (4), 2002, p. 899-922.

[14] Farrell, W. Why Men Earn More. Amacom books, 2004.

[15] Employment in Europe 2003. Luxemburg: Office for Official Publications of the European Communities, 2003.

[16] Labour force, employment and unemployment 1999 2004. Statistics Lithuania: Statistical abstract, 2005. 